\title{
СМЕРТНОСТЬ ОТ ДОРОЖНО-ТРАНСПОРТНЫХ ПРОИСШЕСТВИЙ В МОСКВЕ: АНАЛИЗ СВЯЗАННЫХ ДАННЫХ ПОЛИЦИИ И ГОСУДАРСТВЕННОГО СТАТИСТИЧЕСКОГО УЧЕТА УМЕРШИХ
}

\author{
АНАСТАСИЯ ПЬЯНКОВА, ТИМУР ФАТТАХОВ, \\ КИРИЛЛ БАКАНОВ, ЕЛЕНА ЮРАСОВА
}

\begin{abstract}
В 2016 г. в Москве, по данным полиции, в дорожно-транспортных происшествиях (далее ДТП) погиб 561 человек, тогда как согласно данным органов статистики (если опираться на подход Всемирной организации здравоохранения (далее ВОЗ) к агрегаџии кодов МКБ-10 для определения числа умерших в ДТП, используемый в базе данных «Здоровье для всех») - 790 человек. Для понимания тендениий дорожно-транспортной смертности и для разработки обоснованных и эффективных мер по ее предотвращению необходимы надежные данные, поэтому важно понять причины расхождения чисел погибших в ДТП в Москве по разным официальным источникам информации. Цель исследования - выявить причины, обусловливающие несовпадение чисел погибших по данным полиции и государственной статистики смертности, с помощью связывания записей о погибших в ДТП в Москве в 2016 г. на индивидуальном уровне. В исследовании использовань даннье органов статистики о 1891016 умерших от всех причин смерти и данные полищии о 20302 погибших в ДТП в России в 2016 г. Оба массива информации представляли собой индивидуальные неперсонифицированные записи о погибших. В результате их сопоставления было получено 944 записи с упоминанием Москвы хотя бы в одном из двух источников данных, из которых 699 записей можно рассматривать как связанные, 245 как несвязанные. В 6\% связанных записей код причины смерти, не относится к той группе кодов, которые ВОЗ использует для определения числа умерших в ДТП в базе данных «Здоровье для всех», а в 35\% связанных записей регион регистрации ДТП отличался от региона регистрации смерти. Из 561 записи полиции о погибших 84\% было связано с данными государственной статистики смертности, а из 790 умерших по данным органов статистики 80\% записей связано с данными полищии.
\end{abstract}

Ключевые слова: дорожно-транспортная смертность, связанные данные, данные полиции, государственная статистика смертности, Москва, ВОЗ, ДТП.

\section{ВВЕДЕНИЕ}

Уровень дорожно-транспортной смертности в Москве заметно выделяется на фоне среднероссийских показателей.

АНАСТАСИЯ ИваНОВНА ПьяНКОВА (apyankova@hse.ru), НАЦИОНАЛЬНЫЙ ИССЛЕДОВАТЕЛЬСКИЙ УНИВЕРСИТЕТ «ВЫСШАЯ ШКОЛА ЭКОНОМИКИ», РОССИЯ. ИССЛЕДОВАНИЕ ВЫПОЛНЕНО ПРИ ФИНАНСОВОЙ ПОДДЕРЖКЕ РФФИ В РАМКАХ НАУЧНОГО ПРОЕКТА №19-013-00060

ТИМУР АСФАНОВИч ФАТТАХов (tfattahov@hse.ru), НАЦИОНАЛЬНЫЙ ИССЛЕДОВАТЕЛЬСКИЙ УНИВЕРСИТЕТ «ВЫСШАЯ ШКОЛА ЭКОНОМИКИ», РОССИЯ. ИССЛЕДОВАНИЕ ВЫПОЛНЕНО В РАМКАХ ГРАНТА РНФ №16-18-10324.

КИРИЛЛ СЕРГЕЕВИЧ БАКАНОВ, НАУЧНЫЙ ЦЕНТР БЕЗОПАСНОСТИ ДОРОЖНОГО ДВИЖЕНИЯ МВД РФ, РОССИЯ.

ЕЛЕНА ДМИТРИЕВНА ЮРАСОВА, ПРЕДСТАВИТЕЛЬ ВОЗ В РОССИЙСКОЙ ФЕДЕРАЦИИ, КООРДИНАТОР ПО НЕИНФЕКЦИОННЫМ ЗАБОЛЕВАНИЯМ, РОССИЯ.

СТАТЬЯ ПОСТУПИЛА В РЕДАКЦИЮ В ЯНВАРЕ 2019 Г. 
Если в 2016 г. в России, по данным полиции ${ }^{1}$, общий коэффициент смертности от ДТП составил 13,8 умерших на 100 тыс. человек, то в Москве - 4,5 умерших на 100 тыс., что сопоставимо с показателями таких стран, как Германия (3,9 на 100 тыс. человек), Финляндия (4,7 на 100 тыс. в 2015 г.), Австрия (4,9 на 100 тыс.) ${ }^{2}$.

В то же время в 2018 г. в России была поставлена цель «повысить безопасность на дорогах до минимума и снизить смертность в результате ДТП» ${ }^{3}$. К 2024 г. предполагается снизить уровень смертности до 4 погибших на 100 тыс. человек и обозначена необходимость стремления к нулевому уровню смертности к 2030 г. ${ }^{4}$

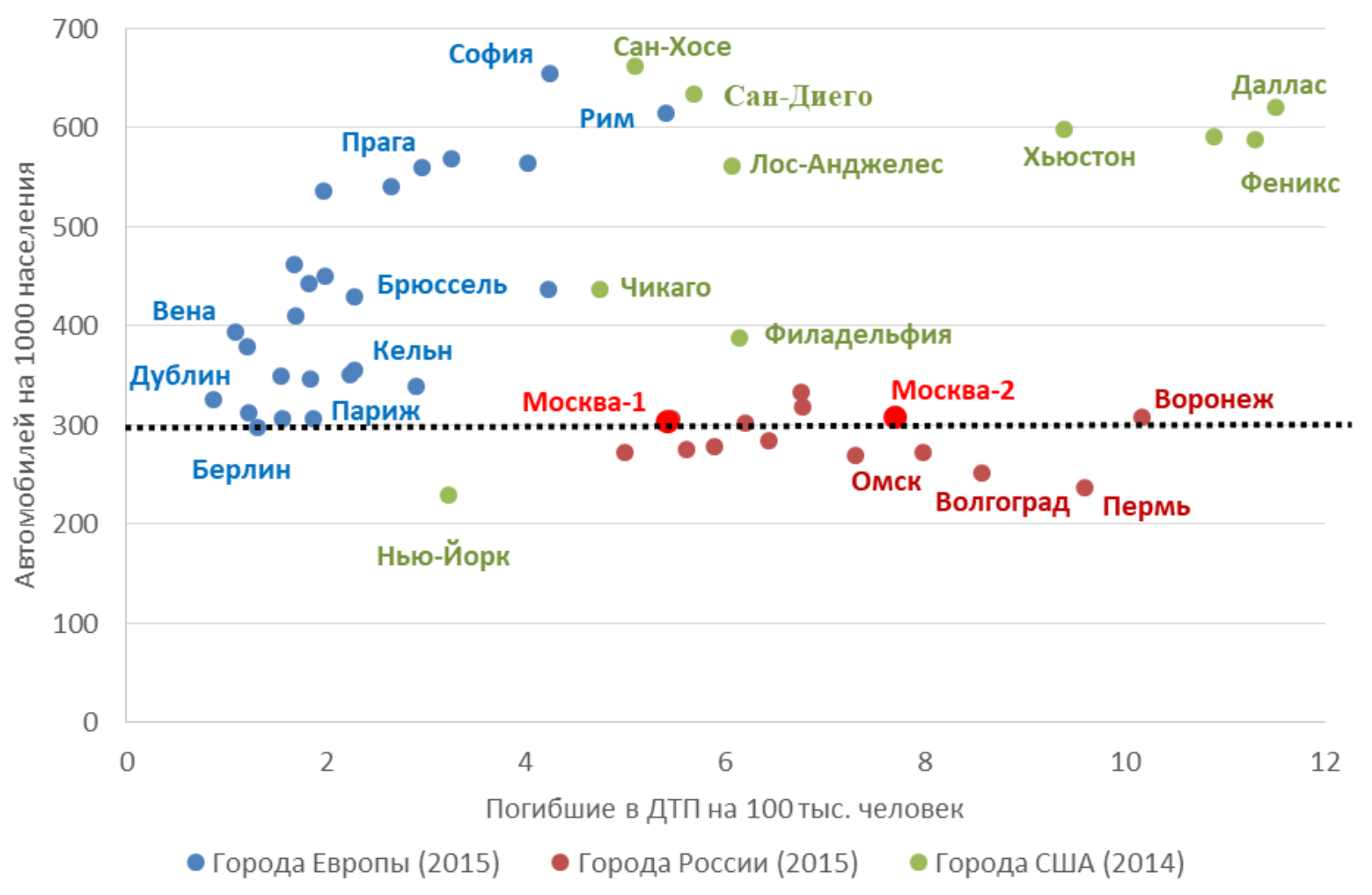

\section{Рисунок 1. Уровень автомобилизации и смертности от ДТП по данным полиции в некоторых городах мира с численностью населения более 1 млн человек}

Источники: российские города - Федеральная служба государственной статистики (далее Росстат); европейские города - URL: http://ec.europa.eu/eurostat/data/database (дата обращения 25.04.2018); города США - URL: http://www.city-data.com (дата обращения 25.04.2018).

Примечание: Москва-1 - данные полищии; Москва-2 - данные статистического учета смертности.

По данным полиции, в Москве уже в 2016 г. были почти достигнуты показатели дорожно-транспортной смертности, запланированные в среднем для России к 2024 г. Однако при сравнении с европейскими городами с населением более 1 млн человек (Дублин, Хельсинки, Берлин, Париж, Лондон и др.) с сопоставимым уровнем

\footnotetext{
1 Здесь и далее под полицией понимается ГИБДД МВД РФ.

${ }^{2}$ https://stats.oecd.org/Index.aspx?DataSetCode=IRTAD_CASUAL_BY_AGE.

${ }^{3}$ Послание Президента РФ Федеральному Собранию от 01.03.2018.

${ }_{4}^{4}$ Распоряжение Правительства РФ от 08.01.18 №1-р «Стратегия безопасности дорожного движения в Российской Федерации на 2018-2024 годы».
} 
автомобилизации (от 295 до 326 автомобилей на 1000 жителей) видно, что уровень дорожно-транспортной смертности в Москве превышает соответствующий показатель в указанных городах в 3-6 раз (рисунок 1). При уровне автомобилизации, характерном для Москвы и других крупных городов России (около 300 автомобилей на 1000 человек), разрыв в уровне смертности от ДТП между максимальным (Воронеж) и минимальным (Новосибирск) показателями двукратный.

Однако если обратиться к данным органов статистики, применив к ним группировку кодов причин смерти МКБ-10, используемую ВОЗ в базе данных «Здоровье для всех» 5 , то уровень дорожно-транспортной смертности в Москве оказывается существенно выше (7,7 погибших на 100 тыс. человек) и положение Москвы на рисунке 1 сдвигается вправо в сторону более высоких показателей дорожно-транспортной смертности.

Расхождения в оценке числа погибших в ДТП по данным органов статистики и полиции существуют во многих странах. В 23 из рассмотренных 39 стран это число по данным органов статистики выше, чем по данным полиции (таблица 1 Приложения). Из них в 11 превышение составляет более 10\%, а максимальные расхождения отмечаются в Португалии и Канаде.

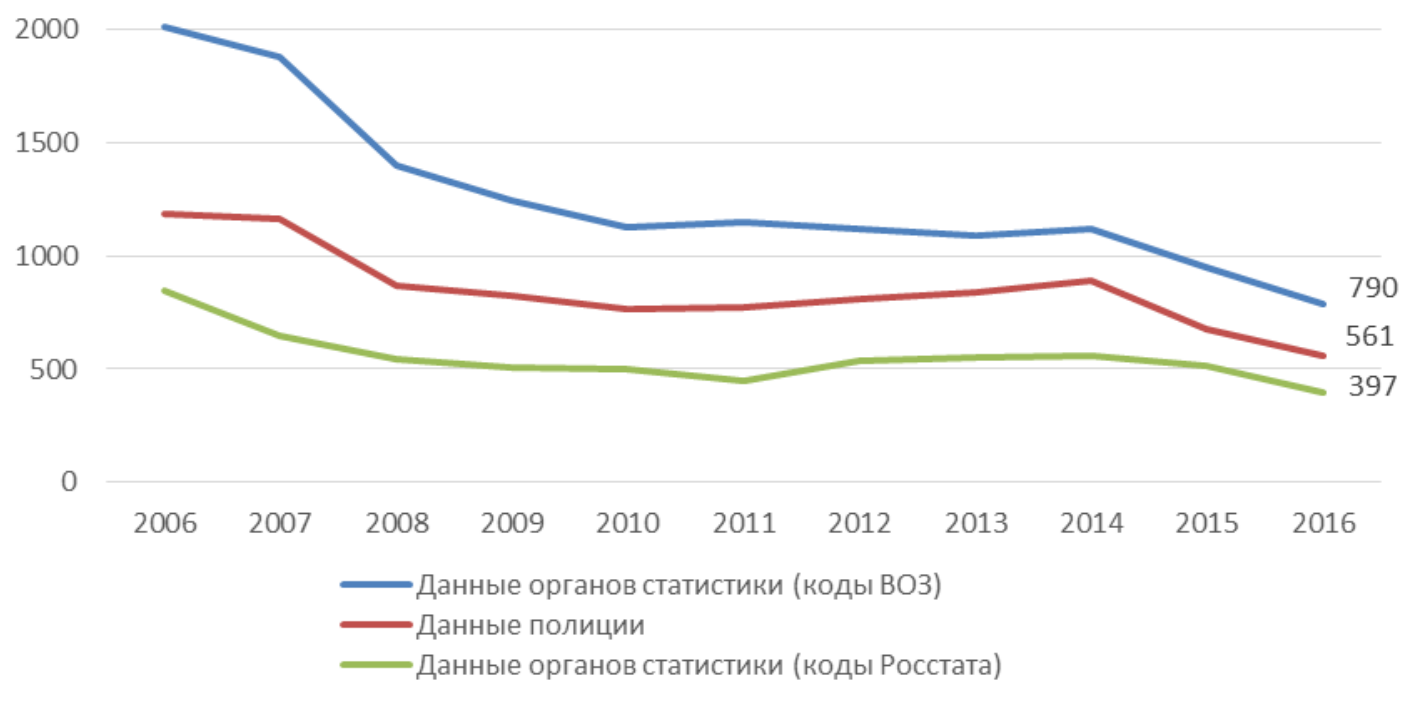

Рисунок 2. Число погибших в ДТП в Москве по разным источникам данных, человек

Источник: Росстат, данные полиции.

Россия относится к группе стран, где число погибших в ДТП по данным органов статистики ниже числа, фиксируемого полицией. В Москве число погибших в ДТП по данным госстатистики (с использованием подхода Росстата к группировке кодов причин смерти МКБ-10 для определения числа умерших от ДТП) на 21,5\% меньше, чем по данным полиции (397 человек или 3,2 на 100 тыс. человек против 561 человек или 4,5 на 100 тыс. человек соответственно). С другой стороны, если сравнивать данные полиции с данными

${ }^{5}$ https://gateway.euro.who.int/en/indicators/hfa_167-1740-sdr-motor-vehicle-traffic-accidents-all-ages-per-100000/visualizations/\#id=19098\&tab=notes 
госстатистики, используя группировку кодов причин смерти МКБ-10, применяемую ВОЗ в базе данных «Здоровье для всех», то по данным органов статистики умерших в ДТП на 40\% больше (790 человек или 7,7 на 100 тыс. человек), чем по данным полиции (рисунок 2). Поэтому распространенная проблема расхождения данных о числе погибших в ДТП по данным полиции и органов статистики усугубляется наличием разных подходов к выделению категории лиц, умерших в ДТП, по данным госстатистики.

На недоучет числа погибших в ДТП в случае использования только одного источника информации было обращено внимание еще в начале 1990-х годов [International traffic safety...1994], в настоящее время это положение общепризнано [Derrik, Mak 2007].

Поскольку ДТП - причина смерти, по которой ведется, как минимум, двойной учет событий, использование техники связывания (record linkage) в исследованиях стало распространенным в мировой практике подходом к оценке полноты учета смертельных и несмертельных исходов ДТП на основе разных источников информации. Этот подход получил признание еще в конце 1980-х - начале 1990-х годов [Fife 1989; Clark 1993; Rosman, Rnuiman 1994] и особенно широкое распространение с середины 2000-х годов [Clark 2004; Boufous, Finch 2006; Petridou et al. 2009] с развитием компьютерных технологий и программного обеспечения. В последние годы число исследований, использующих несколько источников информации для оценки уровня и структуры недоучета смертности и травматизма в результате ДТП, растет. Часть из них фокусируется только на оценке числа погибших [Hu, Baker, Baker 2011; Kudryavtsev et al. 2013], другая - только на оценке числа раненых [Broughton et al 2010; Short, Caulfield 2016]. Однако увеличивается количество исследований, охватывающих оба вида последствий ДТП, смертельные и несмертельные исходы [Petridou et al. 2009; Yannis 2014; Waatson, Waatson, Vallmuur 2015; Janstrup et al 2016; Mandacaru et al. 2017].

Несмотря на то, что умершие в ДТП учитываются в целом лучше, чем раненые, ситуация может варьироваться по странам. На примере Китая было показано, что коэффициенты смертности от ДТП при использовании данных статистики смертности в 2 раза выше, чем при использовании данных полиции, что свидетельствует о недоучете умерших в данных полиции [Hu, Baker, Baker 2011]. На примере Эфиопии установлено, что недоучет умерших может иметь место в обоих источниках информации, однако в данных полиции он в 2 раза ниже, чем в данных медицинских учреждений [Abegaz et al. 2014]. На примере же других стран показана обратная ситуация. Так, недоучет умерших в ДТП практически отсутствует в данных полиции по сравнению с данными органов статистики в России (Архангельск) [Kudryavtsev et al. 2013], с данными медицинских учреждений в Дании [Janstrup et al. 2016], с данными объединенной системы учета скорой медицинской помощи в Греции [Petridou et al. 2009].

Помимо недоучета умерших и раненых, существует проблема кодирования ДТП как причины смерти в медицинских свидетельствах о смерти. На примере Бразилии [Mandacaru et al. 2017] и России [Kudryavtsev et al. 2013] при сравнении данных полиции с данными органов статистики выявлена неудовлетворительная фиксация ДТП в качестве причины смерти в медицинских свидетельствах о смерти, в том числе в результате использования 
«мусорных кодов» МКБ-10 (V89, V99, Y32) и плохо определенных причин смерти (18 класс МКБ-10, коды R00-R99).

Накопленные доказательства ограниченности раздельного использования существующих источников данных о последствиях ДТП привели к тому, что в докладе ВО3, посвященном безопасности на дорогах, постулирована необходимость гармонизации данных о ДТП и их последствиях из разных источников. Показано, что в 25 странах в качестве официальных данных о числе погибших в ДТП используются связанные данные из разных источников [World health organization 2015:11].

В данном исследовании Москва была выбрана, с одной стороны, как регион, отражающий общероссийскую проблему расхождения числа погибших в ДТП по данным полиции и органов статистики, с другой стороны, как регион, достигший минимального уровня дорожно-транспортной смертности в России. Помимо этого, Москва является ярким представителем группы регионов России, где проблема расхождения числа погибших в ДТП по разным официальным источникам информации ярко выражена. Это обстоятельство может вести к выбору неверных, дезориентирующих целевых показателей и смещению приоритетов в области политики безопасности дорожного движения.

Таким образом, основная цель исследования заключалась в использовании связанных индивидуальных неперсонифицированных записей о погибших в ДТП в Москве для выявления и количественной оценки роли различных факторов, ведущих к расхождению числа погибших по данным полиции и органов статистики. Кроме того, связывание записей на индивидуальном уровне даёт возможность оценить наличие и масштаб проблем с кодированием ДТП в качестве причины смерти в медицинских свидетельствах о смерти.

\section{ДАННЫЕ}

Исследование основывалось на двух источниках информации: на данных государственной статистики смертности и данных о погибших в ДТП, предоставляемых полицией.

$$
\text { Данные госстатистики представляли собой индивидуальные }
$$

неперсонифицированные записи об умерших в России в 2016 г., базирующиеся на медицинских свидетельствах о смерти. В случае ДТП такие свидетельства, как правило, заполняются судебно-медицинскими экспертами ${ }^{6}$ (в 2016 г. в Москве ими было выдано 100\% медицинских свидетельств). Медицинские свидетельства о смерти собираются органами ЗАГС, которые обязаны ежемесячно передавать индивидуальные записи об умерших и их социально-демографических характеристиках в электронном формате в территориальные органы Росстата 7 . Эти данные, в отличие от данных полиции, не привязаны к определению смерти от ДТП в 30-дневный период после происшествия.

\footnotetext{
${ }^{6}$ Письмо Министерства здравоохранения и социального развития РФ от 30.09.11 №14-9/10/2-9696 «Об особенностях кодирования травм при дорожно-транспортных происшествиях в соответствии с МКБ-10». ${ }^{7}$ Постановление Правительства РФ от 21.11.13 №1049 «Об утверждении Правил представления органами записи актов гражданского состояния сведений о государственной регистрации рождения, смерти, заключения и расторжения брака в Федеральную службу государственной статистики».
} 
Поэтому человек, умерший от последствий ДТП спустя 30 дней после происшествия, попадает только в данные органов статистики.

Росстат трактует как являющиеся следствием ДТП только те смерти, для которых указаны следующие четырехзначные коды блока рубрик «транспортные несчастные случаи»: V01.1- V04.1, V09.2-3, V10.3-9-V39.3-9, V40.4-9-V79.4-9, V83.2-V86.2. Эти коды относятся к «дорожным несчастным случаям» ${ }^{8}$ и не включают «недорожные несчастные случаи» и «не определённые как дорожные или недорожные несчастные случаи», что ведет к неполному отражению числа погибших в ДТП в источниках информации, использующих такой подход (рисунок 2). Поэтому для определения числа умерших в результате ДТП мы опирались на несколько иной подход к агрегации кодов МКБ-10, используемый в базе данных ВО3 «Здоровье для всех» и позволяющий не ограничиваться только «дорожными несчастными случаями», а рассматривать все смерти, отнесенные к рубрикам V02-V04, V09, V12-V14, V20-V79, V82-V87, V89. В соответствии с таким подходом в Москве в 2016 г. в ДТП погибло 790 человек. По каждому случаю были доступны следующие переменные: дата рождения и смерти (число, месяц, год), пол, место регистрации смерти (регион), зарегистрированное место жительства пострадавшего (регион), четырехзначный код причины смерти по МКБ-10. Категория участника дорожного движения и характер происшествия определялась на основе четырехзначного кода МКБ-10.

Использованные нами данные полиции также представляли собой индивидуальные неперсонифицированные записи о погибших в дорожно-транспортных происшествиях в России в 2016 г. Первоисточником для них служит карточка учета ДТП. В соответствии с этими данными в Москве в 2016 г. погиб 561 человек. В государственную статистическую отчетность полиции о погибших в результате ДТП включаются сведения только о погибших на месте ДТП или умерших от последствий ДТП в течение 30 суток. В течение этого срока на основании медицинских уведомлений ${ }^{9}$ и сверок в базу данных полиции могут вноситься изменения относительно статуса раненого, если он умер в стационаре. Если в результате ДТП возбуждено судебное дело, то по таким случаям изменения могут вноситься в течение года. По каждому случаю ДТП были доступны следующие переменные: 1) дата (число, месяц, год) и время ДТП, место регистрации ДТП (регион, район); 2) персональные характеристики умершего (дата рождения - число, месяц, год; категория участника дорожного движения - водитель, пассажир, пешеход и др; пол; тяжесть последствий для здоровья в результате ДТП - умер на месте до приезда скорой помощи, по приезду, в ходе транспортировки, далее по каждым суткам от первых до тридцатых).

\footnotetext{
${ }^{8}$ Дорожный несчастный случай по МКБ-10 - это любой несчастный случай, связанный с моторным транспортным средством, произошедший на общественной автомагистрали (т.е. начинающийся, заканчивающийся или в какой-то степени связанный с нахождением этого средства на автомагистрали). Предполагается, что мототранспортный несчастный случай произошел на дороге, если не указано другое место, за исключением несчастных случаев, связанных только с недорожным моторным транспортом, которые классифицируются как несчастные случаи, происшедшие не на общественной автомагистрали, если нет противоречащих этому указаний.

${ }^{9}$ Приказ Министерства здравоохранения РФ от 26.01.09 №18 «Об утверждении статистического инструментария по учету пострадавших в дорожно-транспортных происшествиях».
} 


\section{МЕТОДЫ}

На первом этапе исследования были определены переменные, по которым происходило сопоставление и поиск идентичных записей в двух источниках информации. К переменным, которые по своему содержанию были идентичны в обеих базах данных, относились только дата рождения и пол умершего. В данных полиции дата рождения отсутствовала в 16 записях (2,8\% всех записей), еще в 38 случаях (6,8\% всех записей) дата рождения была установлена частично, был указан только год рождения. В данных статистических органов дата рождения умершего не была установлена в 13 случаях (1,6\% записей), еще в 6 случаях (0,8\% записей) был установлен только год рождения. Возможно, достаточно высокая доля записей полиции с частично установленной датой рождения погибшего объясняется тем, что при заполнении этого поля в карточке учета ДТП название соответствующего пункта раздела «Участники ДТП» сформулировано как «год рождения», а указания о необходимости зафиксировать день и месяц рождения отсутствуют ${ }^{10}$. В предоставленных данных полиции пол пострадавшего в 30\% случаев не был определен, тогда как в данных статистических органов пол умершего определен во всех случаях.

Классификация категорий участников дорожного движения в данных органов статистики полностью не совпадала с классификацией, используемой полицией.

Другие переменные, которые мы сначала предполагали использовать для поиска совпадений в двух базах, имели разное по смыслу содержание.

Так, учет умерших органами статистики ориентирован на сбор данных о социальнодемографических характеристиках умершего человека, тогда как данные полиции - на случай ДТП и связанные с ним характеристики. Поэтому в данных органов статистики фиксируется дата смерти человека (число, месяц, год), тогда как в данных полиции - дата дорожно-транспортного происшествия. Они, конечно, могут не совпадать. Дата смерти человека установлена во всех 790 записях в данных органов статистики.

Дата смерти участника ДТП по данным полиции определялась, исходя из даты ДТП, которая точно установлена во всех 561 случае. В части случаев дата ДТП по данным полиции полностью совпадала с датой смерти по данным органов статистики (332 записи), во всех остальных случаях (229 записей), когда даты не совпадали, к дате ДТП прибавляли от -1 до 30 суток и искали записи с соответствующей датой смерти в данных госстатистики.

По той же причине разного фокуса систем учета событий, погибшие в ДТП в данных полиции привязаны к месту регистрации происшествия (вплоть до географических координат). В учёте же органов статистики фиксируется регион регистрации смерти, который может не совпадать ни с регионом, где произошло ДТП, ни с регионом наступления смерти. Исходя из действующего законодательства, вариантов места регистрации смерти может быть множество ${ }^{11}$. Поэтому регион (места происшествия или

\footnotetext{
${ }^{10}$ Постановление Правительства Российской Федерации от 29.06.1995 (ред. от 27.08.18) № 647 «Об утверждении Правил учета дорожно-транспортных происшествий».

${ }^{11}$ По последнему месту жительства умершего, месту наступления смерти, месту обнаружения тела умершего, месту нахождения организации, выдавшей документ о смерти, месту жительства родителей (одного из родителей), детей, пережившего супруга или по месту нахождения суда, вынесшего решение об 
регистрации смерти) в нашем исследовании не мог выступать в качестве основной связующей переменной.

В итоге в качестве основных связующих переменных были выбраны только дата рождения и дата смерти (число, месяц, год) погибшего в ДТП. Записи считались совпавшими, если:

- точно совпадали число, месяц, год даты рождения и даты смерти погибшего в двух источниках данных при условии, что одной записи из данных полиции соответствовала только одна запись из данных госстатистики.

- 1 или 2 части даты рождения или даты смерти погибшего различались.

Сначала совпадающие записи искали среди кодов МКБ-10, которые ВОЗ использует в базе данных «Здоровье для всех» (см. раздел Данные, изначально очерченные 790 записей).

Затем было решено расширить группу кодов для поиска, исходя из предположения, что оставшаяся часть записей полиции о погибших может кодироваться другими транспортными кодами, не входящими в группу используемых ВО3, а также кодами, относящимися к внешним причинам с прямым упоминанием автомобильного транспорта. К ним были отнесены следующие коды блоков рубрик:

- «Транспортные несчастные случаи» (V01, 05-06, 15, 18-19, 80, 88, 93, 97-99);

- «Нападение» (Y02-03);

- «Повреждение с неопределенными намерениями» (Y31-32);

- «Последствия воздействия внешних причин заболеваемости и смертности» (Y85).

Далее, основываясь на не раз отмечавшейся «популярности» в России блока кодов «повреждения с неопределенными намерениями» [Васин 2015] и на предположении о возможности кодирования смертей от ДТП другими кодами внешних причин смерти, оставшиеся записи полиции сопоставляли с данными госстатистики, где в качестве основной причины смерти фигурировали все другие внешние причины смерти, кроме упомянутых выше. В заключение, учитывая возможность смерти от естественной причины, в результате которой произошло ДТП, а также использование «неточно обозначенных и неизвестных причин смерти» (18-й класс МКБ-10) для кодирования дорожно-транспортной смертности [Mandacaru et al. 2017], мы расширили круг поиска до всех остальных классов причин смерти.

Возможность обратиться ко всем индивидуальным данным статистики смертности, зафиксированных органами госстатистики, и данным полиции в России за 2016 г. позволила найти совпавшие записи как в случае совпадения региона ДТП и регистрации смерти, так и в тех случаях, когда они не совпадали.

установлении факта смерти или объявлении лица умершим, или многофункционального центра предоставления государственных и муниципальных услуг, на который возложены полномочия в соответствии с пунктом 2.2 статьи 4 Федерального закона от 15.11.1997 №143-Ф3 (ред. от 03.08.18) «Об актах гражданского состояния»). 


\section{РезУльтаты}

В результате связывания было получено 944 записи с упоминанием Москвы хотя бы в одном из двух источников данных как места регистрации ДТП и/или места регистрации смерти, из которых 699 записей можно рассматривать как связанные (ячейки, залитые зеленым в таблице 1), 245 - как несвязанные (ячейки, залитые оранжевым в таблице 1), из которых 89 присутствуют только в данных полиции, 156 - только в данных государственной статистики смертности.

По данным полиции, в 2016 г. зафиксирован 561 погибший в результате ДТП, произошедших в Москве. Из них смерть в 414 случаях была зарегистрирована также в Москве, а 24 - в других регионах России, в обоих случаях группой кодов причин смерти, выделяемых ВО3 как ДТП.

\section{Таблица 1. Число связанных записей о погибших в ДТП в Москве и других регионах} России и несвязанных записей, 2016

\begin{tabular}{|c|c|c|c|c|c|c|c|}
\hline & \multicolumn{4}{|c|}{ Число записей по данным органов статистики } & \multirow{3}{*}{$\begin{array}{c}\text { Число } \\
\text { записей } \\
\text { полиции, } \\
\text { несвязанных } \\
\text { с данными } \\
\text { органов } \\
\text { статистики }\end{array}$} & \multirow{3}{*}{$\begin{array}{c}\text { Всего } \\
\text { (по строке) }\end{array}$} \\
\hline & & \multicolumn{2}{|c|}{$\begin{array}{c}\text { Группа кодов, выделяемых } \\
\text { ВО3 }\end{array}$} & \multicolumn{2}{|c|}{$\begin{array}{c}\text { Все другие коды } \\
\text { причин смерти }\end{array}$} & & \\
\hline & & $\begin{array}{c}\text { Москва } \\
\text { регион } \\
\text { регистрации } \\
\text { смерти } \\
\end{array}$ & $\begin{array}{c}\text { Другие } \\
\text { регионы } \\
\text { регистрации } \\
\text { смерти } \\
\end{array}$ & $\begin{array}{c}\text { Москва } \\
\text { регион } \\
\text { регистрации } \\
\text { смерти } \\
\end{array}$ & $\begin{array}{c}\text { Другие } \\
\text { регионы } \\
\text { регистрации } \\
\text { смерти } \\
\end{array}$ & & \\
\hline \multirow{2}{*}{$\begin{array}{l}\text { Число } \\
\text { записей } \\
\text { полиции }\end{array}$} & $\begin{array}{l}\text { Москва - } \\
\text { регион } \\
\text { регистрации } \\
\text { ДТП } \\
\end{array}$ & 414 & 24 & 33 & 1 & 89 & 561 \\
\hline & $\begin{array}{l}\text { Другие } \\
\text { регионы } \\
\text { регистрации } \\
\text { ДТП } \\
\end{array}$ & 220 & 0 & 7 & 0 & - & 227 \\
\hline \multicolumn{2}{|c|}{$\begin{array}{l}\text { Число записей из данных } \\
\text { органов статистики, } \\
\text { несвязанных с данными } \\
\text { полиции }\end{array}$} & 156 & - & - & - & - & 156 \\
\hline \multicolumn{2}{|c|}{ Всего (по столбцу) } & 790 & 24 & 40 & 1 & 89 & 944 \\
\hline
\end{tabular}

По данным статистического учета смертности, в Москве зарегистрирована смерть в результате ДТП 790 человек (при подходе ВОЗ к агрегации кодов МКБ-10 для определения числа умерших в ДТП, используемом в базе данных «Здоровье для всех»). Из них в 414 случаях факт ДТП также зарегистрирован в Москве, а в 220 - в других регионах России. Смерть еще 41 человека была при кодировании отнесена на счет других причин смерти, но полицией они рассматриваются как умершие в ДТП. Из них смерть в 40 случаях зарегистрирована в Москве (в 33 случаях факт ДТП зарегистрирован в Москве, в 7 - в других регионах России), в 1 случае - в других регионах России.

\section{Число и характеристики связанных и несвязанных данных полиции}

\section{с данными статистического учета смертности}

Из 561 записи о погибших в ДТП в Москве, зафиксированных полицией, 472 записи (84\%) были идентифицированы в данных госстатистики. Из них 414 - в изначально очерченной совокупности умерших в Москве среди 790 погибших. Следует отметить, что, исходя из подхода ВОЗ к агрегации кодов МКБ-10 для определения смерти в результате ДТП, 
указанные 414 записей включают дорожные, недорожные и не определённые (как дорожные или недорожные) транспортные несчастные случаи. Это позволило нам изначально избежать недоучета умерших в ДТП, возникающего при использовании подхода Росстата к агрегации кодов причин смерти для выделения умерших в результате ДТП (см. раздел Данные).

Для поиска возможных совпадений среди оставшихся 147 записей полиции с данными госстатистики список кодов причин смерти был расширен до всех кодов, помимо тех, что используются ВОЗ и соответственно нами на первом этапе. Это позволило идентифицировать еще 33 умерших в Москве, для которых причиной смерти по данным полиции стало ДТП, тогда как по данным статистических органов - другие причины смерти. Наиболее часто встречающиеся коды причин смерти (21 из 33 записей) относятся к другим «транспортным несчастным случаям», не входящим в группу кодов, используемых ВОЗ:

- V05 - пешеход, пострадавший при столкновении с поездом или другим железнодорожным транспортным средством (12 случаев);

- V98-99 - другие и неуточненные транспортные несчастные случаи (5 случаев);

- V06 - пешеход, пострадавший при столкновении с другим немоторным транспортным средством (2 случая);

- V19 - велосипедист, пострадавший в результате других и неуточненных транспортных несчастных случаев (2 случая).

Примеров использования кодов внешних причин, но с прямым упоминанием автомобильного транспорта, найдено не было, но другие внешние причины смерти встречаются часто (10 случаев из 33 записей):

- Y10-Y34 - повреждение с неопределенными намерениями (8 случаев);

- Y49 - лекарственные средства, медикаменты и биологические вещества, являющиеся причиной неблагоприятных реакций при терапевтическом применении (1 случай);

- Х09 - воздействие неуточненных источников дыма, огня и пламени (1 случай).

Редко, но встречаются, примеры использования естественных причин смерти для кодирования записей в случаях, которые полиция рассматривает как ДТП (2 из 33 случаев): болезни системы кровообращения (I25) и новообразования (C25).

Поскольку регион регистрации ДТП и регион регистрации смерти в статистическом учете и в данных полиции могут не совпадать, для дальнейшего поиска возможных совпадений среди оставшихся записей полиции (114) с данными госстатистики список регионов был расширен до всех субъектов России. В результате было найдено 25 совпадающих записей, когда, по данным полиции, местом ДТП была Москва, а местом регистрации смерти - другие регионы России. Интересно, что местом регистрации их жительства во всех случаях являлись те же регионы, где была зарегистрирована смерть. Как и предполагалось, чаще всего среди регионов встречалась Московская область (84\% 
или 21 из 25), помимо нее по одной смерти от ДТП было зарегистрировано в Кировской, Самарской, Тюменской областях и Республике Чувашия.

89 умерших от ДТП, зафиксированных полицией, не удалось идентифицировать среди всех умерших в России в 2016 г. Возможно, это связано с ошибками в регистрации дат смерти и/или рождения, а также с возможностью несовпадения годов регистрации смерти. Так, ДТП могло произойти и быть соответственно зафиксировано полицией в 2016 г., а смерть от ДТП произошла и зафиксирована в данных госстатистики в 2017 г., к которым у нас не было доступа.

Таблица 2. Характеристики связанных и несвязанных данных полиции о погибших в ДТП в Москве с данными госстатистики об умерших в России в 2016 г.

\begin{tabular}{|c|c|c|c|c|c|c|c|c|}
\hline & & & & Из г & $\begin{array}{l}\text { Iх по кодам пр } \\
\text { мерти МКБ- } 10\end{array}$ & & & $\partial^{\circ}$ \\
\hline & & 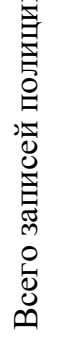 & 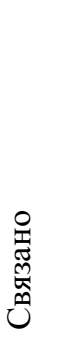 & 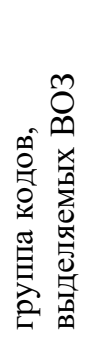 & 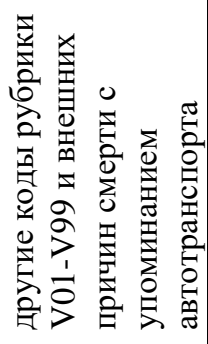 & 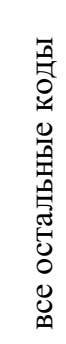 & 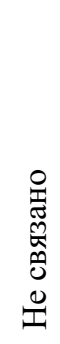 & 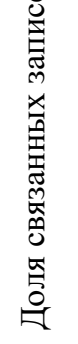 \\
\hline Всего & & 561 & 472 & 438 & 22 & 12 & 89 & 84,1 \\
\hline & Мужчины & 264 & 228 & 206 & 12 & 10 & 36 & 86,4 \\
\hline Пол & Женщины & 117 & 91 & 89 & 2 & 0 & 26 & 77,8 \\
\hline & Неизвестно & 180 & 153 & 143 & 8 & 2 & 27 & 85 \\
\hline & $0-14$ & 3 & 3 & 2 & 1 & 0 & 0 & 100 \\
\hline & $15-24$ & 66 & 66 & 62 & 2 & 2 & 7 & 100 \\
\hline & $25-34$ & 143 & 125 & 115 & 4 & 6 & 18 & 87,4 \\
\hline & $35-44$ & 97 & 87 & 80 & 6 & 1 & 12 & 89,7 \\
\hline Возраст & $45-54$ & 53 & 45 & 42 & 3 & 0 & 10 & 84,9 \\
\hline & $55-64$ & 82 & 58 & 54 & 3 & 1 & 18 & 70,7 \\
\hline & $65-74$ & 33 & 28 & 26 & 0 & 2 & 5 & 84,8 \\
\hline & $75+$ & 68 & 57 & 54 & 3 & 0 & 10 & 83,8 \\
\hline & Неизвестно & 16 & 3 & 3 & 0 & 0 & 9 & 18,8 \\
\hline & Пешеходы & 296 & 235 & 215 & 17 & 3 & 61 & 79,4 \\
\hline & Велосипедисты & 1 & 1 & 0 & 1 & 0 & 0 & 100 \\
\hline Категория участника & Водители & 180 & 162 & 149 & 4 & 9 & 18 & 90 \\
\hline дорожного движения & Пассажиры & 83 & 73 & 73 & 0 & 0 & 10 & 88 \\
\hline & Другие участники & 1 & 1 & 1 & 0 & 0 & 0 & 100 \\
\hline & Неизвестно & 0 & 0 & 0 & 0 & 0 & 0 & - \\
\hline
\end{tabular}

Половозрастные характеристики исходных и связанных записей полиции, представленные в таблице 2, свидетельствуют о нескольких особенностях. Во-первых, наибольшая доля связанных записей характерна для молодых возрастов (до 24 лет), что свидетельствует о высокой точности фиксации даты рождения, даты ДТП и, возможно, о лучшем информационном взаимодействии между полицией и учреждениями здравоохранения в случае гибели детей и молодых людей. В то же время в пенсионных возрастах доля связанных записей самая низкая и колеблется от 70 до 85\%. Во-вторых, доля связанных записей для водителей и пассажиров выше (90 и 88\% соответственно), чем для пешеходов (79\%). Суммируя, можно сказать, что такие группы, как пожилые, женщины, пешеходы - наиболее уязвимые группы, с точки зрения качества фиксации данных. 
Пожилые (55+) женщины-пешеходы - та группа, где доля связанных записей наивысшая (72\%) по сравнению с пожилыми мужчинами - пешеходами (52\%) и тем более по сравнению с пожилыми водителями-мужчинами (40\%).

\section{Число и характеристики связанных и несвязанных данных} статистического учета смертности с данными полиции

Из изначально очерченной совокупности умерших в ДТП в Москве по данным органов статистики (790 человек) 634 записи были связаны (80\%) с данными полиции, которые на определенном этапе были расширены до всех погибших в ДТП во всех субъектах России. Из них 414 (65\% связанных с данными полиции) были идентифицированы в Москве. Возможность обратиться ко всей базе данных полиции позволила идентифицировать еще 220 (35\%) погибших в ДТП в других регионах РФ, но чья смерть была зарегистрирована в Москве. Данные госстатистики позволили определить, что местом жительства этих погибших была Москва. Из 220 москвичей, погибших в ДТП в других регионах (всего 23 региона), 87\% погибли в близлежащих к Москве шести областях: Московской (63\%), Тульской (7\%), Владимирской (5\%), Рязанской (5\%), Тверской (5\%), Калужской (2\%).

Исходя из предположения, что часть смертей, рассматриваемых полицией как гибель в ДТП, органами статистики может быть отнесена на счет других причин смерти, мы расширили поиск совпадающих записей с указанием всех остальных кодов причин смерти, помимо кодов, используемых ВОЗ. Это позволило идентифицировать в данных госстатистики еще 41 умершего вследствие ДТП. В этих случаях были указаны коды других причин смерти, помимо используемых ВО3, тогда как полиция определяла их как ДТП. Из них 33 были идентифицированы в Москве (подробно они описаны в разделе выше), а 7 в других регионах РФ, закодированы они также были кодами V05 (5 случаев) и V98-99 (2 случая).

Оставшиеся 156 записей текущего учета не удалось связать с данными полиции.

Половозрастные характеристики исходных и связанных записей органов статистики (таблица 3) свидетельствуют о том, что лица в возрастах 45-64 года, мужчины, пешеходы наиболее уязвимые группы, с точки зрения качества фиксации данных.

Последняя колонка таблицы 3 показывает, что для пешеходов в основном характерно совпадение региона ДТП и региона регистрации смерти (81\% от связанных записей). Для защищенных участников дорожного движения (водителей и пассажиров) ситуация обратная: на фоне высокой доли связанных записей для этой категории регион ДТП и регион регистрации смерти совпадают не чаще чем в $30 \%$ случаев. Последнее относится и к ДТП с детьми (0-14 лет) - ДТП с ними происходят в основном в других регионах, но смерть фиксируется в Москве. Высокие доли связанных записей для защищенных участников дорожного движения и детей (0-14) достигаются за счет того, что в данном исследовании была возможность обратиться к данным полиции о погибших во всех регионах России в 2016 г., в противном случае доля связанных записей для этих категорий участников дорожного движения была бы очень низкой. 
Таблица 3. Характеристики связанных и несвязанных данных об умерших, зарегистрированных органами статистики в Москве, с данными полиции о погибших в ДТП в России в 2016 г.

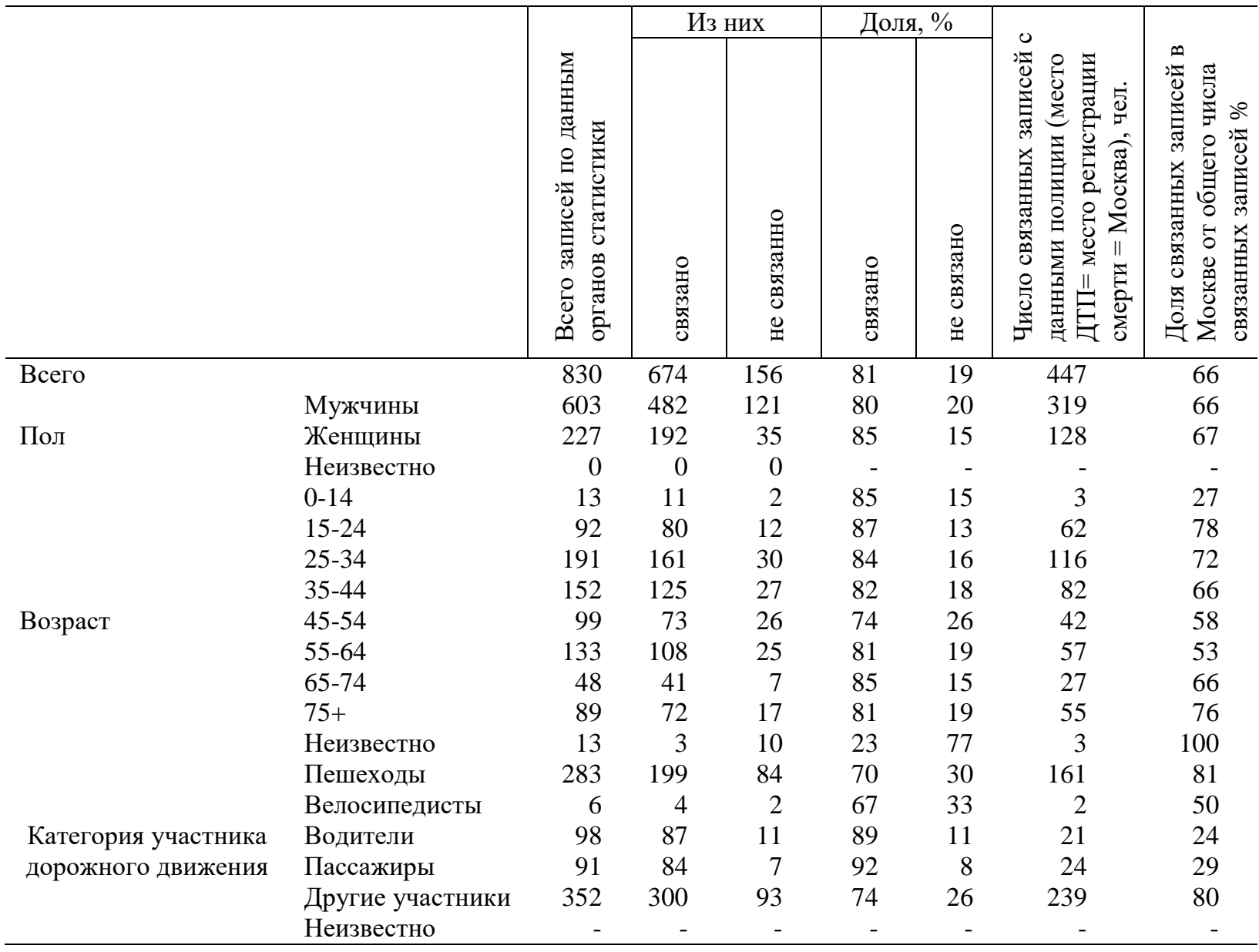

\section{Практика кодирования ДТП в качестве причины смерти}

Обобщая практику кодирования ДТП в качестве причины смерти, которые были зафиксированы полицией в Москве (561), можно сказать, что в 78\% случаев были применены коды, используемые ВОЗ для определения числа погибших в ДТП, в 6\% случаев - другие коды причин смерти, в 16\% случаев не удалось связать записи полиции с данными органов статистики.

В практике кодирования ДТП в качестве причины смерти (произошедших как в Москве, так и за ее пределами), можно выделить три особенности. Во-первых, наиболее употребляемые коды (19 из 41 связанных записей) предназначены для кодирования случаев, произошедших с пешеходами, пострадавшими при столкновении с немоторными транспортными средствами (V05 и V06). В основном эти коды употребляются для случаев наезда поезда на пешехода и соответственно не должны попадать в статистику смертности от ДТП. В случае же их фиксации в статистике полиции это не могут быть случаи попадания пешехода под поезд, в том числе электропоезд пригородного сообщения. Дополнительные характеристики данных полиции (отсутствие транспортного средства и его характеристик, категория участника ДТП) и устные консультации с представителями полиции свидетельствуют, что в большинстве случаев (16 из 19) это наезд трамвая на пешехода, 
следовательно - это ДТП по определению полиции. Поэтому часть случаев записей текущей статистики смертности, где используются коды V05 и V06, стоит относить к дорожно-транспортной смертности. Однако структура этих кодов не позволяет выделить эти записи напрямую. Оценить долю подобных случаев возможно только с помощью сопоставления с данными полиции.

Вторая ожидаемая особенность заключается в «популярности» группы кодов «повреждения с неопределенными намерениями» (Ү10-Ү34) - 8 из 41 записи. В международной практике ${ }^{12}$ эта группа кодов используется редко (таблица 1 Приложения). Те коды этого блока, где указано место смерти (Ү33-34 - улица или автомагистраль), используются еще реже, единственным исключением является Япония. Чаще же всего эти коды причин смерти используются в России. Поэтому можно считать нецелесообразным их использование в кодировании причин смерти, если есть основания полагать, что случай связан с ДТП. В этих случаях следует использовать транспортные коды V87-V89.

Третья по частоте использования группа кодов - «другие и неуточненные транспортные несчастные случаи (V98-V99)» (7 случаев из 41). Их следует рассматривать как «мусорные» транспортные коды и не применять, тем более они используются в очень небольшом числе стран (таблица 1 Приложения), преимущественно восточноевропейских (Болгария, Сербия, Румыния, Польша).

\section{ОБСУЖДЕНИЕ}

Можно предположить, что одной из причин расхождения в числе погибших по данным полиции и органов статистики может служить наличие 30-дневного срока регистрации смерти от ДТП в системе учета полиции и отсутствие этого ограничения в данных статистического учета смертности. Соответственно какая-то часть смертей в результате ДТП может происходить и фиксироваться в данных статистического учета смертности после истечения этого срока. Однако на основе анализа связанных данных в Москве в 2016 г. был обнаружен лишь один подобный случай, а в России - всего 20. Следовательно, использование полицией 30-дневного срока не может объяснять значительные расхождения в данных о числе погибших в результате ДТП как в Москве, так и в России.

Помимо этого, можно предположить, что некоторые зарегистрированные органами статистики смерти от ДТП на самом деле могут объясняться естественными причинами смерти [Routley et al. 2003] или самоубийствами [Gauthier et al. 2015; Svensson 2018] и, соответственно, влиять на разницу в числе погибших по разным источникам данных. Однако в Москве в 2016 г. было выявлено всего 2 случая смерти от естественных причин, рассматриваемые полицией как ДТП, и ни одного суицида. В целом для России практика применения транспортных суицидальных кодов (X81-82) не распространена (таблица 2 Приложения). Так, в 2016 г. в России органами статистики эти коды были применены к 49

12 Было рассмотрено 39 стран, предоставляющих данные ВОЗ о причинах смерти в формате четырехзначного кода МКБ- 10. 
случаям смерти, из которых ни один случай не был идентифицирован в данных полиции за этот год.

Основная же причина расхождений в числе погибших по данным полиции и органов статистики в России, в том числе и в Москве, - отсутствие в МКБ-10 понятия «смерть, наступившая в результате ДТП» в отличие от предыдущих версий МКБ. Вследствие этого возникает проблема выбора подхода к группировке дорожно-транспортных кодов для оценки числа умерших в ДТП. Одним из решений проблемы несопоставимости данных госстатистики и полиции в России может служить переход Росстата на использование кодов, применяемых ВОЗ в базе данных «Здоровье для всех». Однако это дает только приближенное соответствие определению ${ }^{13}$, установленному Правилами государственного учета ДТП и Глоссарием по статистике транспорта ${ }^{14}$.

Кроме того, в нашем исследовании было выявлено еще несколько причин, определяющих расхождения в числе умерших в ДТП по данным полиции и госстатистики.

Во-первых, это особенности кодирования транспортных несчастных случаев в России, прежде всего использование блока кодов «повреждения с неопределенными намерениями» (Y10-34), а также «других и неуточненных транспортных несчастных случаев» (V98-99). В Москве суммарно на коды, не относящиеся к группировке кодов, используемой ВО3 в базе данных «Здоровье для всех», приходится 6\% от общего числа связанных записей (41 из 699).

Вторая причина расхождений числа умерших в ДТП по данным полиции и госстатистики - это привязка к разным местам регистрации событий, что ведет к несопоставимости этих данных на региональном уровне. Она обусловливает $35 \%$ случаев от общего числа связанных записей (252 из 699). В многонаселенных регионах небольшой площади с высокой транспортной мобильностью (таких как Москва) число умерших по данным полиции будет, скорее, ниже, чем по данным госстатистики. Такие регионы формируют вокруг себя ареал регионов-соседей, где фиксируются ДТП, тогда как смерть регистрируется в регионе выезда.

Помимо этого, как в базе данных полиции, так и в базе госстатистики могут быть ошибки регистращии событий. Это подтверждается наличием расхождений в датах рождения умерших в ДТП. Иногда имеет место неполная информация об умерших. Неустановленная дата рождения или дата смерти умершего в ДТП в одной базе данных часто приводит к тому, что нет возможности идентифицировать этот случай в другой базе данных.

Полиция, в соответствии с законодательством, имеет возможность проводить сверки с медицинскими учреждениями об умерших и раненых в ДТП. На деле же возможности проведения сверок ограничены, так как медицинские организации зачастую отказывают в

\footnotetext{
${ }^{13}$ Дорожно-транспортное происшествие - событие, возникшее в процессе движения по дороге транспортного средства и с его участием, в котором погибли или ранены люди, повреждены транспортные средства, сооружения, грузы либо причинен иной материальный ущерб.

https://www.unece.org/fileadmin/DAM/trans/main/wp6/pdfdocs/glossru4.pdf

${ }^{14}$ Федеральный закон от 10.12.1995 №196-Ф3 «О безопасности дорожного движения».
} 
допуске к свидетельствам о смерти, результатам экспертиз, ссылаясь на закон о защите врачебной тайны.

Кроме того, учреждения системы здравоохранения должны предоставлять в органы внутренних дел по месту нахождения медицинской организации извещение о раненом, скончавшемся в течение 30 суток после ДТП. Однако в ходе личных консультаций представители Научного центра безопасности дорожного движения МВД РФ сообщили, что подобные извещения практически не поступают, возможно, потому, что указанные положения соответствующего приказа ${ }^{15}$ носят рекомендательный характер. К тому же их сложно выполнить, поскольку извещение с указанием причины смерти по МКБ-10 должно быть направлено медицинской организацией в срок не более одних суток после смерти пострадавшего в орган внутренних дел РФ по месту своего нахождения, тогда как причина смерти в случае ДТП должна быть точно установлена в ходе медицинского исследования трупа судебно-медицинским экспертом или патологоанатомом. Срок (число дней) подобного исследования жестко не установлен и исчисляется со дня поступления в бюро судебно-медицинской экспертизы постановления или определения о назначении экспертизы и прилагаемых к нему объектов и материалов, необходимых для проведения экспертизы и выдачи экспертного заключения, по день окончания оформления экспертного заключения и его подписания исполнителем ${ }^{16}$. Период проведения медицинского исследования трупа явно превышает 1 сутки.

Как показало исследование, в данных статистического учета смертности существуют проблемы с точностью определения кода причины смерти. С одной стороны, медицинские свидетельства в случае ДТП, как правило, заполняются судебномедицинскими экспертами, у которых должно быть постановление или направление правоохранительных органов о назначении судебно-медицинского исследования. В них указываются сведения (тип транспортного средства, описание транспортного происшествия, категория участника дорожного движения погибшего, характер происшествия - дорожное/недорожное), которые должны вести к весьма низкой доле записей, закодированных нетранспортными и неутонченными транспортными кодами ${ }^{17}$. На практике, возможно, судебно-медицинские эксперты и патологоанатомы получают меньше информации о ДТП, чем должны, что сказывается на точности определения причины смерти, в частности кодирования обстоятельств ДТП, а именно отнесения ДТП к одной из категорий: дорожное; недорожное; не уточнённое как дорожное или недорожное; происшествие при посадке или высадке. Неполноту информации о ДТП в данных статистического учета смертности можно заметить при распределении погибших в ДТП по категориям участников дорожного движения и характеру несчастного случая (таблица 4). Видно, что категория участника дорожного движения часто не определена судебно-

\footnotetext{
15 Приказ Министерства здравоохранения РФ от 26.01.09 №18 «Об утверждении статистического инструментария по учету пострадавших в дорожно-транспортных происшествиях».

${ }^{16}$ Приказ Министерства здравоохранения и социального развития РФ от 12.05 .10 №346н «Об утверждении порядка организации и производства судебно-медицинских экспертиз в государственных судебноэкспертных учреждениях Российской Федерации».

${ }^{17}$ Письмо Министерства здравоохранения и социального развития РФ от 30.09.11 №14-9/10/2-9696 «Об особенностях кодирования травм при дорожно-транспортных происшествиях в соответствии с МКБ-10».
} 
медицинскими экспертами или патологоанатомами однозначно (в 333 случаях из 790 погибший отнесен к категории «неуточненный как водитель или пассажир»). Если же погибший определен как пешеход, то тогда, в большинстве случаев, не определен характер ДТП, хотя эта информация должна содержаться в постановлениях или направлениях правоохранительных органов на судебно-медицинскую экспертизу.

Таблица 4. Распределение умерших в ДТП в Москве по категориям участников дорожного движения и характеру происшествия по данным статистического учета смертности, 2016, человек

\begin{tabular}{l|c|c|c|r}
\hline & $\begin{array}{c}\text { Дорожный } \\
\text { несчастный } \\
\text { случай }\end{array}$ & $\begin{array}{c}\text { Недорожный } \\
\text { несчастный } \\
\text { случай }\end{array}$ & $\begin{array}{c}\text { Неуточненный } \\
\text { как дорожный } \\
\text { или недорожный }\end{array}$ & Итого \\
\hline Пешеход & 82 & 3 & 179 & 264 \\
Водитель & 81 & 20 & - & 101 \\
Пассажир & 84 & 8 & - & 92 \\
Неуточненный как водитель или пассажир & 324 & 9 & - & 333 \\
Итого & 571 & 40 & 179 & 790 \\
\hline
\end{tabular}

Примечание: Прочерк означает отсутствие в МКБ-10 данного характера происшествия для соответствующих категорий участников дорожного движения.

Заключая, можно сказать, что законодательные предпосылки для информационного обмена между полицией и учреждениями здравоохранения существуют, но на практике взаимодействие налажено слабо, что и отражается на полноте и точности данных о погибших в ДТП в данных статистического учета смертности.

\section{ОГРАНИЧЕНИЯ}

Исследование не было лишено ограничений. Его предметом выступали только умершие, и это, конечно, очень важно, так как в России человеческие потери от дорожно-транспортной смертности все еще непозволительно высоки. Но за пределами исследования остались раненные в ДТП, хотя бремя травматизма в развитых странах не меньше бремени смертности в результате ДТП.

Выбранная территория исследования (Москва) все же не отражает общероссийскую ситуацию и является специфичным регионом. Развитая транспортная инфраструктура, высокий уровень автомобилизации и большие финансовые возможности делают Москву практически несопоставимой с другими регионами России по возможностям повышения уровня безопасности дорожного движения. Тем не менее пример Москвы отражает ситуацию, характерную для определенной группы регионов с высокой транспортной мобильностью населения и развитыми транспортными связями.

Выбор одного региона предопределил ограниченное число наблюдений. С другой стороны, это позволило осуществить их поиск вручную во всех других регионах России по данным госстатистики и полиции.

Несоответствие даты регистрации ДТП в полиции и даты регистрации смерти в органах госстатистики заставило нас использовать применительно к данным полиции 
расчетную дату смерти, определяемую, исходя из точной даты ДТП и даты смерти по данным госстатистики, что могло приводить к ложно связанным записям.

Более длительный период наблюдения позволил бы в какой-то степени решить проблему малого числа наблюдений, а также оценить тенденции последних лет. Но, к сожалению, используемые в исследовании данные труднодоступны, что и не позволило расширить его временны́е рамки.

Причины достаточно большого числа несовпадений (всего 245 несвязанных записей, из них 89 присутствуют только в данных полиции, 156 - только в данных госстатистики) остались невыявленными, в отличие от подобного исследования, проведенного в Архангельске [Kudryavtsev et al. 2013]. Помимо этого, отсутствие имени и фамилии или вместо них идентификационного номера как наиболее точного способа идентификации человека могло приводить к ложно связанным записям. Для решения этих проблем можно

было бы использовать существующие законодательные предпосылки для информационного обмена между полицией и учреждениями здравоохранения с использованием персональных данных (фамилия, имя, отчество), как это было выполнено в исследовании на примере Архангельска. Для этих целей можно было бы организовать взаимодействие уполномоченных представителей полиции и медицинских учреждений (в частности, МИАЦ), которые при сверке данных имеют право использовать персональные данные. Однако очные консультации с представителями полиции свидетельствуют о том, что возможности проведения подобных сверок очень сильно ограничены.

\section{ЗАКЛЮЧЕНИЕ}

Умершие в ДТП москвичи часто погибают в других регионах, что ставит вопрос, по какому принципу необходимо оценивать число умерших в ДТП в регионе: по месту наступления происшествия или по месту регистрации смерти. Однако совместное использование данных полиции и госстатистики позволило подробно разобраться в причинах несоответствия данных о погибших в ДТП, полученным из разных источников информации. Выполнение подобного исследования для всей страны позволило бы выявить региональные особенности кодирования ДТП в статистических органах и типологизировать регионы по причинам, определяющим расхождения в числе погибших по данным госстатистики и полиции.

В перспективе целесообразно расширить подобные исследования, включив в анализ данные бюро судебно-медицинских экспертиз, которое могло бы выступить третьим источником информации о погибших в ДТП. К тому же это позволило бы оценить роль алкогольного фактора в дорожно-транспортной смертности в России.

В подобных исследованиях в России наиболее труднореализуемой (поскольку в системе здравоохранения отсутствуют данные необходимого формата), но необходимой задачей является включение в анализ данных о раненых в ДТП. 


\section{ЛИТЕРАТУРА}

Васин С. (2015). Смертность от повреждений с неопределенными намерениями в России и в других странах. Демографическое обозрение, 2(1), 89-124. doi: https://doi.org/10.17323/demreview.v2i1.1790

Abegaz T., Berhane Y., Worku A., Assrat A., Assefa A. (2014). Road traffic deaths and injuries are under-reported in Ethiopia: a capture-recapture method. PLOS ONE, 9(7) e103001. doi: 10.1371/journal.pone.0103001

Boufous S., Finch C. (2006). Record linkage: a tool for injury prevention research. International journal of injury control and safety promotion, 13(4), 267-269. doi: $10.1080 / 17457300600711929$

Broughton J., Keigan M., Yannis G., Evgenikos P., Chaziris A., Papadimitriou E.,...Tecl J. (2010). Estimation of the real number of road causalities in Europe. Safety Science, 48, 365-371. doi: 10.1016/j.ssci.2009.09.012

Clark D.E. (1993). Development of a statewide trauma registry using multiple linked sources of data. Proceedings. Symposium on Computer Applications in Medical Care, 654-8.

Clark D.E. (2004). Practical introduction to record linkage for injury research. Injury Prevention, 10(3), 186-191. doi: 10.1136/ip.2003.004580

Derriks H.M., Mak P.M. (2007). Underreporting of road traffic casualties. IRTAD Special report. Ministry of Transport, Public Works and Water management The Netherlands.

Fife D. (1989). Matching fatal accident reporting system cases with National Center for Health Statistics motor vehicle deaths. Accident Analysis and Prevention, 21, 79-83.

Gauthier S., Reisch T., Ajdacic-Gross V., Bartsch C. (2015). Road traffic suicide in Switzerland. Traffic Injury Prevention, 16(8), 768-772. doi: 10.1080/15389588.2015.1021419

Hu G., Baker T., Baker S. (2011). Comparing road traffic mortality rates from police-reported data and death registration data in China. Bulletin of the World Health Organization, 89(1), 41-45. doi: 10.2471/BLT.10.080317

International traffic safety data and analysis group (1994). Underreporting of road traffic accidents reported by the police at the international level. IRTAD Special report, OECD, Paris.

Janstrup K.H., Kaplan S., Hels T., Lauritsen J., Prato C.G. (2016). Understanding traffic crash under-reporting: Linking police and medical records to individual and crash characteristics. Traffic Injury Prevention, 17(6), 580-584. doi: 10.1080/15389588.2015.1128533

Kudryavtsev A.V., Kleshchinov N., Ermolina M., Lund J., Grjibovski A.M., Nilssen O., Ytterstad B. (2013). Road traffic fatalities in Arkhangelsk, Russia in 2005-2010: reliability of police and healthcare data. Accident Analysis and Prevention, 53, 46-54. doi: 10.1016/j.aap.2012.12.022

Mandacaru P.M.P., Andrade A.L., Rocha M.S., Aguiar F.P., Nogueira M.S.M., Girodo A.M.,...Morais Neto OL. (2017). Qualifying information on deaths and serious injuries caused by road traffic in five Brazilian capitals using record linkage. Accident Analysis and Prevention, 106, 392-398. doi: 10.1016/j.aap.2017.06.018

Petridou E.T., Yannis G., Terzidis A., Dessypris N., Germeni E., Evgenikos P.,...Skalkidis I.(2009). Linking emergency medical department and road traffic police casualty data: a tool in assessing the burden of injuries in less resourced countries. Traffic Injury Prevention, 10 (1), 37-43. doi: 10.1080/15389580802526400

Rosman D.L., Rnuiman M.W. (1994). A comparison of hospital and police road injury data. Accident Analysis and Prevention, 26, 215 - 222. doi: 10.1016/0001-4575(94)90091-4 
Routley V., Staines C., Brennan C., Haworth N., Ozanne-Smith J. (2003). Suicide and natural deaths in road traffic: review. Monash University Accident Research Centre, Victoria. Retrieved from http://www.monash.edu.au/miri/ research/reports/muarc216.pdf

Short J., Caulfield B. (2016). Record linkage for road traffic injuries in Ireland using police hospital and injury claims data. Journal of Safety Research, 58, 1-14. doi: 10.1016/j.jsr.2016.05.002

Svensson K. (2018). Analysis of suicides in road traffic in Sweden 2010-2015. Retrieved from https://www.vti.se/en/Publications/Publication/analysis-of-suicides-in-road-traffic-insweden-201_1203720

Waatson A., Waatson B., Vallmuur K. (2015). Estimating under-reporting of road crash injuries to police using multiple linked data collections. Accident Analysis and Prevention, 83, 18 - 25. doi: 10.1016/j.aap.2015.06.011

World health organization (2015). Global status report on road safety 2015. Geneva.

Yannis G. (2014). Modeling road accident injury under-reporting in Europe. European Transport Research Review, 6(4), 425-438. doi: 10.1007/s12544-014-0142-4 


\section{ПРИЛОЖЕНИЕ}

\section{Таблица 1. Соотношение чисел умерших в ДТП по данным полиции и статистического учета смертности в разных странах}

\begin{tabular}{|c|c|c|c|c|c|c|c|c|c|c|c|c|c|c|c|c|c|c|}
\hline \multirow{3}{*}{ Страна } & \multirow{3}{*}{ Год } & \multirow{3}{*}{$\begin{array}{c}\text { Число } \\
\text { умерших } \\
\text { в ДТП по } \\
\text { данным } \\
\text { полиции }{ }^{1}\end{array}$} & \multirow{3}{*}{$\begin{array}{l}\text { Соотношение } \\
\text { числа } \\
\text { умерших по } \\
\text { данным } \\
\text { статистическ } \\
\text { ого учета } \\
\text { смертности и } \\
\text { по данным } \\
\text { полиции, \% }\end{array}$} & \multirow{2}{*}{\multicolumn{2}{|c|}{$\begin{array}{c}\text { Число умерших в } \\
\text { ДТП по } \\
\text { статистическому } \\
\text { учету смертности, } \\
\text { группа кодов, } \\
\text { используемая } \\
\text { ВО3 }^{2} \\
\end{array}$}} & \multicolumn{11}{|c|}{ Прочие коды, которые можно рассматривать как ДТП } & \multirow{3}{*}{ Всего } & \multirow{3}{*}{$\begin{array}{c}\text { Доля } \\
\text { прочих } \\
\text { кодов, } \\
\%\end{array}$} \\
\hline & & & & & & \multicolumn{5}{|c|}{$\begin{array}{c}\text { транспортные коды, не } \\
\text { входящие в группу кодов, } \\
\text { используемых ВОЗ в БД } \\
\text { «Здоровье для всех» }\end{array}$} & \multicolumn{5}{|c|}{$\begin{array}{c}\text { повреждения с } \\
\text { неопределенными } \\
\text { намерениями с участием ТС }\end{array}$} & \multirow[t]{2}{*}{$\begin{array}{c}\text { последствия } \\
\text { транспортного } \\
\text { несчастного } \\
\text { случая }\end{array}$} & & \\
\hline & & & & 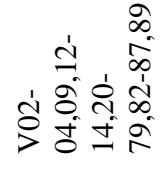 & 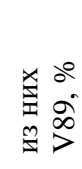 & $\overline{0}$ & $\stackrel{8}{>}$ & $\stackrel{\infty}{>}$ & $\stackrel{\infty}{\infty}$ & $\stackrel{\circ}{\circ}$ & 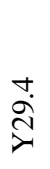 & $\bar{\nu}$ & $\underset{\nu}{\approx}$ & $\underset{\circlearrowright}{\stackrel{\nearrow}{~}}$ & 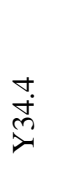 & & & \\
\hline Австралия & 2015 & 1205 & 4,7 & 1262 & 4,5 & 1 & 3 & 8 & 0 & 4 & 0 & 0 & 22 & 0 & 0 & 20 & 1320 & 4,4 \\
\hline Австрия & 2015 & 479 & $-11,1$ & 426 & 37,8 & 0 & 0 & 2 & 0 & 1 & 0 & 8 & 2 & 0 & 0 & 11 & 450 & 5,3 \\
\hline Бельгия & 2015 & 762 & $-15,2$ & 646 & 56,7 & 2 & 0 & 4 & 0 & 0 & 0 & 0 & 0 & 0 & 0 & 6 & 658 & 1,8 \\
\hline Болгария & 2014 & 708 & $-35,9$ & 454 & 17,4 & 0 & 1 & 2 & 2 & 135 & 0 & 0 & 7 & 0 & 0 & 10 & 611 & 25,7 \\
\hline Канада & 2013 & 1860 & 17,8 & 2191 & 22,0 & 1 & 2 & 9 & 1 & 0 & 0 & 0 & 10 & 0 & 0 & 80 & 2294 & 4,5 \\
\hline Хорватия & 2016 & 307 & 15,3 & 354 & 12,7 & 4 & 1 & 0 & 0 & 3 & 0 & 0 & 0 & 0 & 0 & 4 & 366 & 3,3 \\
\hline Чехия & 2016 & 611 & $-7,5$ & 565 & 0,7 & 3 & 1 & 1 & 1 & 6 & 0 & 0 & 1 & 0 & 0 & 5 & 583 & 3,1 \\
\hline Дания & 2015 & 178 & 1,7 & 181 & 0,6 & 1 & 1 & 2 & 0 & 1 & 0 & 0 & 0 & 0 & 0 & 0 & 186 & 2,7 \\
\hline Эстония & 2015 & 67 & 14,9 & 77 & 2,6 & 0 & 0 & 0 & 0 & 0 & 0 & 0 & 0 & 0 & 0 & 1 & 78 & 1,3 \\
\hline Финляндия & 2015 & 270 & $-8,9$ & 246 & 0,4 & 0 & 0 & 1 & 0 & 0 & 0 & 0 & 9 & 0 & 0 & 17 & 273 & 9,9 \\
\hline Франция & 2014 & 3384 & $-15,8$ & 2850 & 72,9 & 1 & 2 & 10 & 0 & 0 & 0 & 0 & 0 & 0 & 0 & 59 & 2922 & 2,5 \\
\hline Грузия & 2015 & 602 & $-7,5$ & 557 & 0,4 & 1 & 0 & 2 & 0 & 59 & 0 & 0 & 0 & 0 & 0 & 0 & 619 & 10,0 \\
\hline Германия & 2015 & 3459 & $-12,4$ & 3030 & 11,9 & 9 & 7 & 14 & 4 & 260 & 0 & 16 & 2 & 0 & 4 & 40 & 3386 & 10,5 \\
\hline Греция & 2015 & 793 & 15,6 & 917 & 33,5 & 0 & 0 & 2 & 0 & 0 & 0 & 0 & 0 & 0 & 0 & 0 & 919 & 0,2 \\
\hline Венгрия & 2015 & 644 & 14,4 & 737 & 0,0 & 0 & 2 & 7 & 0 & 2 & 1 & 23 & 1 & 1 & 3 & 7 & 784 & 6,0 \\
\hline Исландия & 2015 & 16 & $-25,0$ & 12 & 0,0 & 0 & 0 & 0 & 0 & 0 & 0 & 0 & 0 & 0 & 0 & 0 & 12 & 0,0 \\
\hline Израиль & 2015 & 322 & 10,6 & 356 & 5,3 & 0 & 0 & 0 & 5 & 0 & 0 & 0 & 0 & 0 & 0 & 6 & 367 & 3,0 \\
\hline Италия & 2015 & 3428 & 3,7 & 3555 & 8,7 & 4 & 1 & 6 & 1 & 0 & 0 & 0 & 0 & 0 & 0 & 19 & 3586 & 0,9 \\
\hline Япония & 2015 & 4885 & 5,5 & 5153 & 4,1 & 20 & 2 & 2 & 0 & 0 & 1 & 62 & 6 & 8 & 62 & 89 & 5405 & 4,7 \\
\hline
\end{tabular}




\begin{tabular}{|c|c|c|c|c|c|c|c|c|c|c|c|c|c|c|c|c|c|c|}
\hline \multirow{3}{*}{ Страна } & \multirow{3}{*}{ Год } & \multirow{3}{*}{$\begin{array}{c}\text { Число } \\
\text { умерших } \\
\text { в ДТП по } \\
\text { данным } \\
\text { полиции }{ }^{1}\end{array}$} & \multirow{3}{*}{$\begin{array}{c}\text { Соотношение } \\
\text { числа } \\
\text { умерших по } \\
\text { данным } \\
\text { статистическ } \\
\text { ого учета } \\
\text { смертности и } \\
\text { по данным } \\
\text { полиции, \% }\end{array}$} & \multirow{2}{*}{\multicolumn{2}{|c|}{$\begin{array}{c}\text { Число умерших в } \\
\text { ДТП по } \\
\text { статистическому } \\
\text { учету смертности, } \\
\text { группа кодов, } \\
\text { используемая } \\
\text { ВO3 }^{2}\end{array}$}} & \multicolumn{11}{|c|}{ Прочие коды, которые можно рассматривать как ДТП } & \multirow{3}{*}{ Всего } & \multirow{3}{*}{$\begin{array}{c}\text { Доля } \\
\text { прочих } \\
\text { кодов, } \\
\%\end{array}$} \\
\hline & & & & & & \multicolumn{5}{|c|}{$\begin{array}{c}\text { транспортные коды, не } \\
\text { входящие в группу кодов, } \\
\text { используемых ВОЗ в БД } \\
\text { «Здоровье для всех» }\end{array}$} & \multicolumn{5}{|c|}{$\begin{array}{c}\text { повреждения с } \\
\text { неопределенными } \\
\text { намерениями с участием ТС }\end{array}$} & \multirow[t]{2}{*}{$\begin{array}{c}\text { последствия } \\
\text { транспортного } \\
\text { несчастного } \\
\text { случая }\end{array}$} & & \\
\hline & & & & 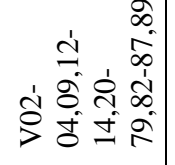 & 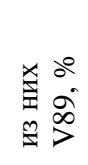 & $\overrightarrow{0}$ & $\stackrel{8}{>}$ & $\stackrel{\infty}{>}$ & $\stackrel{\infty}{>\infty}$ & $\stackrel{2}{>}$ & 芩 & $\vec{\sim}$ & $\stackrel{\sim}{2}$ & $\underset{\infty}{\stackrel{\nu}{~}}$ & 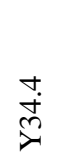 & & & \\
\hline Латвия & 2015 & 188 & 3,2 & 194 & 0,0 & 0 & 0 & 0 & 0 & 0 & 0 & 3 & 1 & 0 & 5 & 3 & 206 & 5,8 \\
\hline Литва & 2015 & 242 & 11,6 & 270 & 1,5 & 0 & 0 & 4 & 0 & 7 & 0 & 0 & 0 & 0 & 0 & 1 & 282 & 4,3 \\
\hline Люксембург & 2015 & 36 & $-30,6$ & 25 & 0,0 & 0 & 0 & 0 & 0 & 0 & 0 & 0 & 0 & 0 & 0 & 0 & 25 & 0,0 \\
\hline Мальта & 2015 & 11 & 9,1 & 12 & 0,0 & 0 & 0 & 0 & 0 & 0 & 0 & 0 & 0 & 0 & 0 & 1 & 13 & 7,7 \\
\hline Нидерланды & 2015 & 621 & $-15,9$ & 522 & 0,4 & 4 & 1 & 1 & 0 & 0 & 0 & 0 & 0 & 0 & 0 & 0 & 528 & 1,1 \\
\hline Н. Зеландия & 2013 & 253 & 13,4 & 287 & 0,0 & 0 & 0 & 1 & 0 & 0 & 0 & 0 & 0 & 0 & 0 & 0 & 288 & 0,3 \\
\hline Норвегия & 2015 & 117 & 10,3 & 129 & 12,4 & 0 & 0 & 0 & 0 & 0 & 0 & 0 & 0 & 0 & 0 & 0 & 129 & 0,0 \\
\hline Польша & 2015 & 2938 & $-9,6$ & 2656 & 1,8 & 1 & 7 & 2 & 1 & 563 & 0 & 0 & 0 & 0 & 0 & 0 & 3230 & 17,8 \\
\hline Португалия & 2014 & 638 & 21,3 & 774 & 57,0 & 1 & 0 & 2 & 1 & 0 & 0 & 0 & 0 & 0 & 0 & 0 & 778 & 0,5 \\
\hline Ю. Корея & 2015 & 4621 & 15,7 & 5346 & 10,9 & 5 & 0 & 0 & 0 & 0 & 0 & 0 & 0 & 0 & 0 & 0 & 5351 & 0,1 \\
\hline Молдавия & 2015 & 300 & 14,3 & 343 & 58,3 & 0 & 0 & 9 & 0 & 0 & 0 & 0 & 0 & 0 & 0 & 0 & 352 & 2,6 \\
\hline Румыния & 2015 & 1893 & 4,3 & 1974 & 69,4 & 0 & 0 & 33 & 0 & 73 & 0 & 0 & 0 & 0 & 0 & 0 & 2080 & 5,1 \\
\hline Сербия & 2015 & 601 & $-36,1$ & 384 & 3,4 & 1 & 2 & 0 & 1 & 119 & 0 & 0 & 0 & 0 & 0 & 0 & 507 & 24,3 \\
\hline Словакия & 2014 & 310 & $-1,6$ & 305 & 0,0 & 0 & 1 & 0 & 0 & 2 & 0 & 0 & 0 & 0 & 0 & 0 & 308 & 1,0 \\
\hline Словения & 2015 & 120 & 3,3 & 124 & 1,6 & 0 & 0 & 1 & 0 & 1 & 0 & 0 & 0 & 0 & 0 & 0 & 126 & 1,6 \\
\hline Испания & 2015 & 1689 & 16,2 & 1962 & 6,1 & 5 & 1 & 10 & 1 & 0 & 0 & 0 & 0 & 0 & 0 & 0 & 1979 & 0,9 \\
\hline Швеция & 2015 & 259 & 1,5 & 263 & 5,7 & 0 & 0 & 2 & 0 & 0 & 0 & 0 & 0 & 0 & 0 & 0 & 265 & 0,8 \\
\hline Швейцария & 2015 & 253 & $-8,7$ & 231 & 24,2 & 0 & 1 & 3 & 0 & 0 & 0 & 0 & 0 & 0 & 0 & 0 & 235 & 1,7 \\
\hline Великобритания & 2015 & 1804 & $-6,0$ & 1695 & 20,0 & 7 & 6 & 11 & 0 & 0 & 0 & 0 & 0 & 0 & 0 & 0 & 1719 & 1,4 \\
\hline США & 2015 & 35092 & 7,2 & 37616 & 32,3 & 0 & 0 & 81 & 21 & 1 & 0 & 0 & 0 & 0 & 0 & 0 & 37719 & 0,3 \\
\hline Россия & 2016 & 20302 & $-6,6$ & 18970 & 4,4 & 9 & 15 & 20 & 22 & 399 & 477 & 150 & 201 & 117 & 76 & 33 & 20489 & 7,4 \\
\hline
\end{tabular}

Источник: 1 - https://stats.oecd.org/; 2 - http://apps.who.int/healthinfo/statistics/mortality/causeofdeath_query/ 
Таблица 2. Число умерших от самоубийств с участием транспортного средства в ряде стран по данным статистического учета

\begin{tabular}{|c|c|c|c|}
\hline Страна & Год & X81 & $\mathrm{X} 82$ \\
\hline Австралия & 2015 & 101 & 35 \\
\hline Австрия & 2015 & 84 & 4 \\
\hline Бельгия & 2015 & 80 & 6 \\
\hline Болгария & 2014 & 9 & 3 \\
\hline Канада & 2013 & 72 & 41 \\
\hline Хорватия & 2016 & 23 & 0 \\
\hline Чехия & 2016 & 106 & 6 \\
\hline Дания & 2015 & 26 & 2 \\
\hline Эстония & 2015 & 4 & 0 \\
\hline Финляндия & 2015 & 40 & 22 \\
\hline Франция & 2014 & 159 & 13 \\
\hline Грузия & 2015 & 5 & 1 \\
\hline Германия & 2015 & 657 & 94 \\
\hline Греция & 2015 & 9 & 2 \\
\hline Венгрия & 2015 & 85 & 1 \\
\hline Исландия & 2015 & 0 & 0 \\
\hline Израиль & 2015 & 5 & 0 \\
\hline Италия & 2015 & 100 & 16 \\
\hline Япония & 2015 & 532 & 1 \\
\hline Латвия & 2015 & 0 & 1 \\
\hline Литва & 2015 & 1 & 0 \\
\hline Люксембург & 2015 & 4 & 1 \\
\hline Мальта & 2015 & 0 & 0 \\
\hline Нидерланды & 2015 & 0 & 0 \\
\hline Н. Зеландия & 2013 & 0 & 0 \\
\hline Норвегия & 2015 & 0 & 0 \\
\hline Польша & 2015 & 0 & 0 \\
\hline Португалия & 2014 & 0 & 0 \\
\hline Ю. Корея & 2015 & 0 & 0 \\
\hline Молдавия & 2015 & 0 & 0 \\
\hline Румыния & 2015 & 0 & 0 \\
\hline Сербия & 2015 & 0 & 0 \\
\hline Словакия & 2014 & 0 & 0 \\
\hline Словения & 2015 & 0 & 0 \\
\hline Испания & 2015 & 0 & 0 \\
\hline Швеция & 2015 & 0 & 0 \\
\hline Швейцария & 2015 & 0 & 0 \\
\hline Великобритания & 2015 & 0 & 0 \\
\hline США & 2015 & 0 & 0 \\
\hline Россия & 2016 & 44 & 5 \\
\hline
\end{tabular}

Источник: http://apps.who.int/healthinfo/statistics/mortality/causeofdeath_query/ 


\title{
ROAD TRAFFIC MORTALITY IN MOSCOW: RECORD LINKAGE STUDY USING POLICE DATA AND VITAL STATISTICS
}

\author{
ANASTASIA PYANKOVA, TIMUR FATTAHOV,
} KIRILL BAKANOV, ELENA YURASOVA

\begin{abstract}
In Moscow, the number of fatalities in road traffic accidents (RTA) in 2016? was, according to police data, 561 people, while Rosstat, using the WHO approach for grouping ICD-10 transport-related codes, puts the number at 790, or 40\% higher. Since reliable data are crucial for estimating road traffic mortality and developing effective road safety measures, it is important to understand the reasons for the discrepancy in the two data sources. The main aim of the research is to identify and quantify the factors causing this discrepancy by linking individual records of those who died in RTA in Moscow in 2016. Mortality statistics (1,891,016 death records) and police data on 20,302 road traffic fatalities in Russia in 2016 were used in the research. Both data sources were individual non-personalized records. According to the WHO approach, 790 people died in RTA in Moscow in 2016, but only 561 persons according to police data.

As a result of the linkage, 944 records were obtained with Moscow mentioned in at least one of the two data sources; of these, 699 records can be regarded as matched, 245 as non-matched. Of the 561 police records, $84.1 \%$ were linked with death records; of the 790 deaths records, $80.3 \%$ were linked with police data.

In $6 \%$ of linked death and police records the ICD-10 codes used are not part of the codes used by the WHO. In $35 \%$ of the linked records, the region of registration of the accident was different from the region of registration of the death.
\end{abstract}

Key words: road traffic accidents, record linkage, police data, death records, vital statistics, Moscow.

Anastasia Pyankova (apyankova@hse.ru), National Research University Higher School of Economics, RUSSIA.

Timur Fattakhov (tfattahov@hse.ru), NATIOnal Research University Higher School of Economics, Russia.

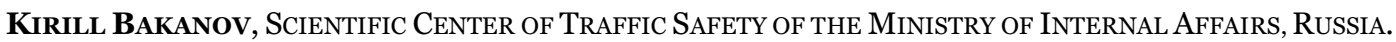

Elena Yurasova, Noncommunicable Diseases WHO OfFice in the Russian Federation, Russia.

THE STUDY WAS IMPLEMENTED UNDER THE GRANT FROM RUSSIAN FOUNDATION FOR BASIC RESEARCH №19-013-00060 AND THE GRANT FROM THE RUSSIAN SCIENCE FOUNDATION №16-18-10324

DATE RECEIVED : JANUARY 2019.

\section{REFERENCES}

Abegaz T., Berhane Y., Worku A., Assrat A., Assefa A. (2014). Road traffic deaths and injuries are under-reported in Ethiopia: a capture-recapture method. PLoS ONE, 9(7) e103001. doi: 10.1371/journal.pone.0103001

Boufous S., Finch C. (2006). Record linkage: a tool for injury prevention research. International journal of injury control and safety promotion, 13(4), 267-269. doi: $10.1080 / 17457300600711929$ 
Broughton J., Keigan M., Yannis G., Evgenikos P., Chaziris A., Papadimitriou E.,...Tecl J. (2010). Estimation of the real number of road causalities in Europe. Safety Science, 48, 365-371. doi: 10.1016/j.ssci.2009.09.012

Clark D.E. (1993). Development of a statewide trauma registry using multiple linked sources of data. Proceedings. Symposium on Computer Applications in Medical Care, 654-8.

Clark D.E. (2004). Practical introduction to record linkage for injury research. Injury Prevention, 10(3), 186-191. doi: 10.1136/ip.2003.004580

Derriks H.M., Mak P.M. (2007). Underreporting of road traffic casualties. IRTAD Special report. Ministry of Transport, Public Works and Water management The Netherlands.

Fife D. (1989). Matching fatal accident reporting system cases with National Center for Health Statistics motor vehicle deaths. Accident Analysis and Prevention, 21, 79-83.

Gauthier S., Reisch T., Ajdacic-Gross V., Bartsch C. (2015). Road traffic suicide in Switzerland. Traffic Injury Prevention, 16(8), 768-772. doi: 10.1080/15389588.2015.1021419

Hu G., Baker T., Baker S. (2011). Comparing road traffic mortality rates from police-reported data and death registration data in China. Bulletin of the World Health Organization, 89(1), 41-45. doi: 10.2471/BLT.10.080317

International traffic safety data and analysis group (1994). Underreporting of road traffic accidents reported by the police at the international level. IRTAD Special report, OECD, Paris.

Janstrup K.H., Kaplan S., Hels T., Lauritsen J., Prato C.G. (2016). Understanding traffic crash under-reporting: Linking police and medical records to individual and crash characteristics. Traffic Injury Prevention, 17(6), 580-584. doi: 10.1080/15389588.2015.1128533

Kudryavtsev A.V., Kleshchinov N., Ermolina M., Lund J., Grjibovski A.M., Nilssen O., Ytterstad B. (2013). Road traffic fatalities in Arkhangelsk, Russia in 2005-2010: reliability of police and healthcare data. Accident Analysis and Prevention, 53, 46-54. doi: 10.1016/j.aap.2012.12.022

Mandacaru P.M.P., Andrade A.L., Rocha M.S., Aguiar F.P., Nogueira M.S.M., Girodo A.M.,...Morais Neto OL. (2017). Qualifying information on deaths and serious injuries caused by road traffic in five Brazilian capitals using record linkage. Accident Analysis and Prevention, 106, 392-398. doi: 10.1016/j.aap.2017.06.018

Petridou E.T., Yannis G., Terzidis A., Dessypris N., Germeni E., Evgenikos P.,...Skalkidis I. (2009). Linking emergency medical department and road traffic police casualty data: a tool in assessing the burden of injuries in less resourced countries. Traffic Injury Prevention, 10 (1), 37-43. doi: 10.1080/15389580802526400

Rosman D.L., Rnuiman M.W. (1994). A comparison of hospital and police road injury data. Accident Analysis and Prevention, 26, 215 - 222. doi: 10.1016/0001-4575(94)90091-4

Routley V., Staines C., Brennan C., Haworth N., Ozanne-Smith J. (2003). Suicide and natural deaths in road traffic: review. Monash University Accident Research Centre, Victoria. Retrieved from http://www.monash.edu.au/miri/ research/reports/muarc216.pdf

Short J., Caulfield B. (2016). Record linkage for road traffic injuries in Ireland using police hospital and injury claims data. Journal of Safety Research, 58, 1-14. doi: 10.1016/j.jsr.2016.05.002

Svensson K. (2018). Analysis of suicides in road traffic in Sweden 2010-2015. Retrieved from https://www.vti.se/en/Publications/Publication/analysis-of-suicides-in-road-traffic-insweden-201_1203720 
Vasin S. (2015). Mortality from undetermined causes of death in Russia and in a selected set of countries. Demographic review, 2(1), 89-124. doi:17323/demreview.v2i1.1790

Waatson A., Waatson B., Vallmuur K. (2015). Estimating under-reporting of road crash injuries to police using multiple linked data collections. Accident Analysis and Prevention, 83, 18 - 25. doi: 10.1016/j.aap.2015.06.011

World health organization (2015). Global status report on road safety 2015. Geneva.

Yannis G. (2014). Modeling road accident injury under-reporting in Europe. European Transport Research Review, 6 (4), 425-438. doi: 10.1007/s12544-014-0142-4 